DOI: $10.5277 /$ epe 160212

\title{
INFLUENCE OF APPLICATION OF ATTAPULGITE ON THE STRUCTURE AND COMPOSITION OF SELF-DYNAMIC MEMBRANE IN BIOREACTORS
}

\begin{abstract}
The effect of application of attapulgite on the structure and composition of a dynamic membrane (DM) of a bioreactor was investigated by means of the electron microscopy, polymerase chain reaction (PCR) and denaturing gradient gel electrophoresis (DGGE). A significant increase of microbial floc size in the bioreactors upon attapulgite application was observed. The content of cake layer in the hybrid dynamic membrane (HDM) and in the dynamic membrane (DM) in the corresponding bioreactor systems were $44.73 \mathrm{~g} / \mathrm{m}^{2}$ and $38.12 \mathrm{~g} / \mathrm{m}^{2}$ respectively, while the contents of mineral $-6.09 \mathrm{~g} / \mathrm{m}^{2}$ and $5.34 \mathrm{~g} / \mathrm{m}^{2}$, respectively. Further, with addition of attapulgite, the concentration of extracellular polymeric substances (EPS) in the HDM bioreactor system decreased, whereas the content of suspended particulate matter increased. Self-DM has a porous structure with high porosity. Mineral substance, including $\mathrm{O}, \mathrm{Ka}, \mathrm{Ca}, \mathrm{P}, \mathrm{S}, \mathrm{Cl}, \mathrm{Mg}$ and $\mathrm{Si}$, are the main elements in $\mathrm{DM}$, but the main elements content exhibited an increase trend in DM with attapulgite administration. These results showed a positive correlation between the quantity of bacterial populations and biological removal improvement, which indicated that application of attapulgite could optimize the structure of self-DM in bioreactors.
\end{abstract}

\section{INTRODUCTION}

The membrane bioreactor, which uses micro-/ultrafiltration membranes to separate solids and liquids, has attracted increasing interest in the field of wastewater treatment due to its reliability, high efficiency, high biomass concentration, small footprint and low sludge production [1]. However, the use of membrane bioreactors still encounters several problems such as high cost of the membrane module, membrane fouling and

${ }^{1}$ College of Environmental Science and Engineering, Anhui Normal University, Wuhu 241003, China, corresponding author W. Duan, e-mail: dws7911@mail.ahnu.edu.cn

${ }^{2}$ Department of Municipal Engineering, Southeast University, Nanjing 210096, China.

${ }^{3}$ Graduate School of Engineering, Tohoku University, Aoba 6-6-06, Sendai 980-8579, Japan. 
high energy consumption [2]. Many membrane bioreactor systems employ flat or hollow fiber membrane filtration modules, which have relatively high energy consumption and require significant care during operation [3, 4]. Therefore, the use of established membrane bioreactor technology is quite limited. Recently, the dynamic membrane (DM) technology for wastewater treatment has gained a great attention due to its costeffective membrane module, reduced energy consumption and improved effluent quality. It is currently regarded a substitution for the conventional membrane bioreactor [5]. For instance, Fuchs et al. [6] replaced MF/UF membrane modules with a mesh filter. Fan and Huang [7] also used mesh filters instead of MF/UF and replaced suction pumping by using gravity head to provide transmembrane pressure for membrane filtration. With further advance in technology [8], nonwoven fabric filters were used in substitution for mesh screens, which also utilized gravity pressure for membrane filtration instead of a pump [9]. These improvements significantly reduced the cost of membrane separation and lowered the energy consumption.

Quite recently, a hybrid membrane bioreactor has been created as a new technique for wastewater treatment [10]. Lesage et al. [11] compared the performance between a membrane bioreactor and a hybrid membrane bioreactor in treating synthetic water with toxic compounds. Bio-diatomite dynamic membrane reactor has been developed for municipal wastewater treatment [12]. Al-Malack et al. [13] studied the backwash methods for a $\mathrm{MnO}_{2}$ dynamic membrane formed on a multifilament woven polyester mesh for domestic wastewater treatment.

Attapulgite (AT) clay is a crystalline hydrated magnesium silicate with a fibrous morphology, large specific surface area and moderate cation exchange capacity, which is beneficial for adsorption of heavy metals in the target solution [14]. There is a large reserve of AT in South China (Jiang Su, Zhe Jiang and An Hui provinces) and in the USA (Florida). AT was first utilized in the 1940s, and now has been usually used as absorbent or catalyst carriers, densifying agents, adhesives and food additives [15]. In recent years, attapulgite, as an environment-friendly adsorptive material, has attracted an increasing attention from many scholars who engage in the research field of environment protection $[14,15]$. Attapulgite could be used as a carrier for microorganisms, and the microbial colonies could form zoogloeas on attapulgite particles through microbial capsules and surface mucus.

To explore the role of attapulgite in bioreactors, assessing its effect on the structure and composition of self-dynamic membrane is a crucial step. However, there is so far no report on this issue. Using particle size analyzer and other techniques, we compared in this study the structure and composition of DM between submerged DM bioreactor and hybrid dynamic membrane (HDM) bioreactor with the addition of attapulgite. The structure and abundance of bacterial community in membrane bioreactors were evaluated with polymerase chain reaction (PCR) and denaturing gradient gel electrophoresis (DGGE) techniques, attempting to disclose any correlations between the quantity of bacterial populations and biological removal improvement. 


\section{MATERIALS AND METHODS}

Experimental set up and operation conditions. Two lab-scale submerged membrane bioreactors were constructed using the same type of membrane module and identical reactor volume (Fig. 1).

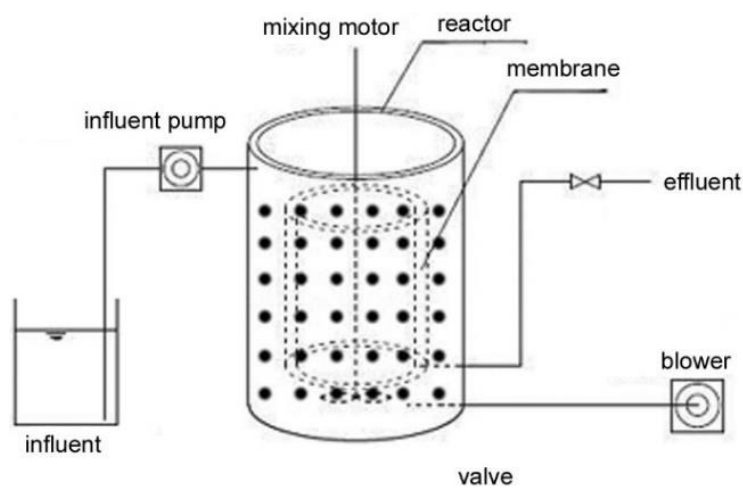

Fig. 1. Schematic diagram of the DM bioreactor

The bioreactor process consisted of an automatic control system and a reactor tank with a situated DM filter (polyethylene non-woven filter module). The total and working volume of the bioreactor tank were $25 \mathrm{dm}^{3}$ and $20 \mathrm{dm}^{3}$, respectively. The DM filter was submerged in the reactor tank with a $0.15 \mathrm{~m}^{2}$ double-sided effective filtration area (Fig. 2) [16].
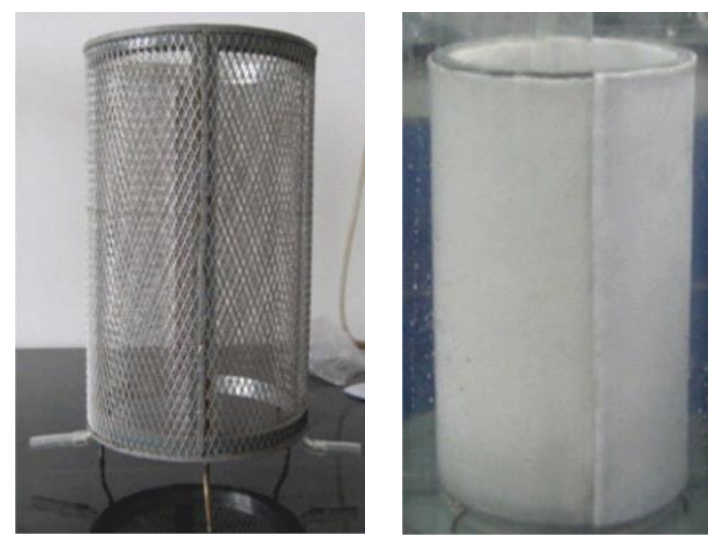

Fig. 2. Photographs of the membrane

Non-woven filter module was made of a nonwoven polyester fabric $4 \mathrm{~mm}$ thick which has a nominal pore size of $100 \mu \mathrm{m}$ and a specific weight of $0.71 \mathrm{~kg} / \mathrm{m}^{2}$ [16]. The diameter of the cylindrical support was $18 \mathrm{~cm}$. The system employed two peristaltic 
pumps (Enertech ENPD-100 Optima, India), one was for intermittent feeding the influent and another for withdrawing permeates from the filter module. The two laboratory scale bioreactors run in parallel with a hydraulic retention time (HRT) of $6 \mathrm{~h}$ and solids retention time (SRT) of $50 \mathrm{~d}$, which were achieved by discharging the mixed liquor from the bioreactor once a day. The membrane flux was set around $62 \mathrm{dm}^{3} /\left(\mathrm{m}^{2} \cdot \mathrm{h}\right)$.

An aeration unit was placed below the filter module, serving as ventilation for the activated sludge. The total aeration rate was $2.6-4.5 \mathrm{dm}^{3} / \mathrm{min}$, and the dissolved oxygen (DO) concentration was $2-4 \mathrm{mg} / \mathrm{dm}$. A temperature control system was installed to keep the temperature range of $20-22{ }^{\circ} \mathrm{C}$. All data were gained automatically in a sequencing flow mode, in which the time of filling, anaerobic, aerobic and discharging was 30,150, 150 and $30 \mathrm{~min}$, respectively. The bioreactors were firstly inoculated with $6-7 \mathrm{~g} / \mathrm{dm}^{3}$ seed activated sludge from a local municipal wastewater treatment plant (China, Nanjing). Attapulgite particles with an equivalent diameter of 5-10 $\mathrm{mm}$ were supplied to the bioreactor during the cultivation stage to reach a concentration of about $0.5 \mathrm{~g} / \mathrm{dm}^{3}$ in the reactor tank [16]. The chemical structure of attapulgite is shown in Fig. 3. Table 1 shows the operating condition of a sequencing DM bioreactor system.

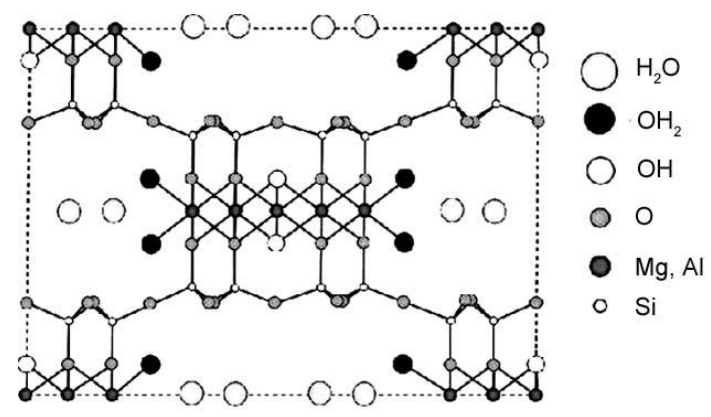

Fig. 3. Chemical structure of attapulgite

Table 1

Operating conditions of the DM bioreactor system

\begin{tabular}{|l|c|}
\hline Flux, $\mathrm{dm}^{3} /\left(\mathrm{m}^{2} \cdot \mathrm{h}\right)$ & 60 \\
\hline Temperature, ${ }^{\circ} \mathrm{C}$ & $20-22$ \\
\hline HRT, $\mathrm{h}$ & 6 \\
\hline SRT, days & 50 \\
\hline Membrane flux, $\mathrm{dm}^{3} /\left(\mathrm{m}^{2} \cdot \mathrm{h}\right)$ & 25 \\
\hline Reactor volume, $\mathrm{dm}^{3}$ & 0.15 \\
\hline Effective filtration area, $\mathrm{m}^{2}$ & 0.15 \\
\hline DO concentration, $\mathrm{mg} / \mathrm{dm}^{3}$ & $2-4$ \\
\hline
\end{tabular}

Analytical equipment and methods. Turbidity, chemical oxygen demand (COD), total nitrogen (TN), total phosphorus (TP) and ammonium ion $\left(\mathrm{NH}_{4}^{+}-\mathrm{N}\right)$ in the raw and 
treated wastewater were analyzed according to Chinese State Environmental Protection Agency (SEPA) Standard Methods [17]. Turbidity was measured with a turbidity meter (Model 2100N, Hach, USA). The membrane flux was assessed by the volumetric method with a graduated cylinder. The concentration of dissolved oxygen (DO) in the bioreactor was examined by a dissolved oxygen meter (Model YSI 58, YSI Research Inc., OH, USA). The particle size distribution of mixed liquors was monitored with a Marlvern counter (Zeta100, United Kingdom).

DNA extraction and nested PCR. Genomic DNA was extracted from the pellets using a Fast DNA spin kit (Bio101, Qbiogene Inc., Carlsbad, CA) with a small modification at the initial step: $1 \mathrm{~cm}^{3}$ of sodium phosphate buffer solution was added and mixed with the sample by a hand-held blender, and then the tube was sonicated for $30 \mathrm{~s}$ on ice. The remaining steps followed the manufacturer's instructions. The product from DNA extraction was verified by electrophoresis in $0.7 \mathrm{vol} \%$ agarose. To minimize the variation in DNA extraction, the templates used for nested PCR quantification were prepared from the mixture of DNA which was extracted in triplicate for each sample.

DGGE fingerprints and statistical analysis. The PCR-amplified DNA fragments were separated on polyacrylamide gels ( 8 vol. $\%, 37.5: 1$ acrylamide-bisacryl-amide) in $0.5 \mathrm{TAE}$ buffer ( $20 \mathrm{mM}$ tris-acetate, $10 \mathrm{mM}$ sodium acetate, $0.5 \mathrm{mM} \mathrm{Na}_{2} \mathrm{EDTA}, \mathrm{pH} 7.4$ ) using a denaturing gradient ranging from $30 \%$ to $60 \%$ (100\% denaturant contains $7 \mathrm{M}$ urea and 40 vol. $\%$ formamide). The amplicons were purified with Wizard PCR preps (Promega), and then aliquots $\left(2 \mathrm{~cm}^{3}\right)$ of purified amplicons were quantified densitometrically. For DGGE, $100 \mathrm{ng}$ of purified amplicons were used. DGGE was performed using a D-Code system (Bio-Rad Laboratories, Inc., Tokyo Japan). Electrophoresis initiated at $60^{\circ} \mathrm{C}$ for $20 \mathrm{~min}$ at $100 \mathrm{~V}$, and thereafter for $5 \mathrm{~h}$ at $200 \mathrm{~V}$. Following electrophoresis, the gel was soaked for 15 min in SYBR Gold (Molecular Probes; Eugene, OR, USA) and then visualized with a UV transilluminator (302 $\mathrm{nm})$.

The nested PCR amplicons were separated on polyacrylamide gels (8 vol. \%, 37.5:1 acryl amide-bisacrylamide) with a 35-55\% linear gradient of denaturant (100\% denaturant $7 \mathrm{M}$ urea plus $40 \%$ formamide). The gels were run for $7 \mathrm{~h}$ at $150 \mathrm{~V}$ in $1 \times \mathrm{TAE}$ buffer (40 Mm tris-acetate, $20 \mathrm{mM}$ sodium acetate, $1 \mathrm{mM} \mathrm{Na} 2 \mathrm{EDTA}, \mathrm{pH}$ 7.4) maintained at $60^{\circ} \mathrm{C}$. Denaturing gradient gels were poured and run by using the DGGE-2001 System (C.B.S. Scientific, Del Mar, CA, USA) after electrophoresis, gels were silverstained and developed [17], then air dried and scanned. The gel images were analyzed with the software Quantity (manufacturer), and DGGE fingerprints were manually scored by the presence of bands with consideration for band brightness intensity. This was done at least three times to ensure consistent results.

Simulated raw water. In order to minimize the variations in feed conditions, synthetic wastewater was supplied to the two bioreactors. The synthetic wastewater (Table 2) [18] contained $1000 \mathrm{mg} / \mathrm{dm}^{3}$ of acetate, $190 \mathrm{mg} / \mathrm{dm}^{3}$ of $\mathrm{NH}_{4} \mathrm{Cl}, 224 \mathrm{mg} / \mathrm{dm}^{3}$ of 
$\mathrm{KH}_{2} \mathrm{PO}_{4}, 90 \mathrm{mg} / \mathrm{dm}^{3}$ of $\mathrm{MgSO}_{4}$ and $37 \mathrm{mg} / \mathrm{dm}^{3}$ of $\mathrm{KCl}$. The trace element solution contained $50 \mathrm{mg} / \mathrm{dm}^{3}$ of EDTA, $22 \mathrm{mg} / \mathrm{dm}^{3}$ of $\mathrm{ZnSO}_{4} \cdot 7 \mathrm{H}_{2} \mathrm{O}, 8.2 \mathrm{mg} / \mathrm{dm}^{3}$ of $\mathrm{CaCl}_{2} \cdot 2 \mathrm{H}_{2} \mathrm{O}, 5.1 \mathrm{mg} / \mathrm{dm}^{3}$ of $\mathrm{MnCl}_{2} \cdot 4 \mathrm{H}_{2} \mathrm{O}, 5.0 \mathrm{mg} / \mathrm{dm}^{3}$ of $\mathrm{FeSO}_{4} \cdot 7 \mathrm{H}_{2} \mathrm{O}, 1.1 \mathrm{mg} / \mathrm{dm}^{3}$ of $\left(\mathrm{NH}_{4}\right)_{6} \mathrm{Mo}_{7} \mathrm{O}_{24} \cdot 4 \mathrm{H}_{2} \mathrm{O}$, $1.8 \mathrm{mg} / \mathrm{dm}^{3}$ of $\mathrm{CuSO}_{4} \cdot 5 \mathrm{H}_{2} \mathrm{O}$ and $1.6 \mathrm{mg} / \mathrm{dm}^{3}$ of $\mathrm{CoCl}_{2} \cdot 6 \mathrm{H}_{2} \mathrm{O}$. pH was kept at 7.0 by dosages of $1 \mathrm{M} \mathrm{HCl}$ and $1 \mathrm{M} \mathrm{NaOH}$.

Table 2

Quality of raw wastewater

\begin{tabular}{|l|c|c|c|c|c|}
\hline Analysis item & $\begin{array}{c}\mathrm{COD} \\
{\left[\mathrm{mg} / \mathrm{dm}^{3}\right]}\end{array}$ & $\begin{array}{c}\mathrm{NH}_{4}-\mathrm{N} \\
{\left[\mathrm{mg} / \mathrm{dm}^{3}\right]}\end{array}$ & $\begin{array}{c}\mathrm{TN} \\
{\left[\mathrm{mg} / \mathrm{dm}^{3}\right]}\end{array}$ & $\begin{array}{c}\mathrm{TP} \\
{\left[\mathrm{mg} / \mathrm{dm}^{3}\right]}\end{array}$ & $\mathrm{pH}$ \\
\hline Value & $173-506$ & $36.9-79.1$ & $50.7-93.4$ & $1.57-6.43$ & $7-8$ \\
\hline Average & 294 & 57.2 & 72.8 & 3.57 & 7.5 \\
\hline
\end{tabular}

\section{RESULTS AND DISCUSSION}

\subsection{DYNAMIC MEMBRANE STRUCTURE}

Addition of attapulgite $\left(0.5 \mathrm{~g} / \mathrm{dm}^{3}\right)$ significantly enhanced the efficiency of HDM bioreactor system in removing COD, TN and TP when compared with that of DM bioreactor without attapulgite [16]. For example, addition of attapulgite improved the COD removal with the COD concentration in effluent decreasing from $12.64 \mathrm{mg} \cdot \mathrm{dm}^{-3}$ to $10.88 \mathrm{mg} \cdot \mathrm{dm}^{-3}$. TN removal was enhanced by $26 \%$ with addition of attapulgite, reaching $77 \%$. TP removal was improved more significantly with the removal efficiency of $75 \%$ (enhanced by 25\%), which could result from a concurrent adsorption and chemical precipitation on attapulgite [18]. The formation of DM structure is very important for membrane operation and separation. Hence, it is needed to characterize the structure of the DM. Before normal filtration, the biomass layer starts to form DM on the support membrane. DM can be divided into cake layer and gel layer [19]. Cake layer is composed of sludge, colloid, volatile suspended particulate matter, inorganic substances, etc. [19]. Our results (Table 3) showed that the content of HDM in the HDM bioreactor system was $44.73 \mathrm{~g} / \mathrm{m}^{2}$. With attapulgite addition, the content of EPS in the HDM decreased from $8.83 \mathrm{~g} / \mathrm{m}^{2}$ to $4.98 \mathrm{~g} / \mathrm{m}^{2}$, whereas the content of volatile suspended solids (VSS) matter increased from $25.96 \mathrm{~g} / \mathrm{m}^{2}$ to $30.31 \mathrm{~g} / \mathrm{m}^{2}$. The content of the mineral substances in the HDM increased from $5.34 \mathrm{~g} / \mathrm{m}^{2}$ to $5.59 \mathrm{~g} / \mathrm{m}^{2}$. The volatile suspended solids (VSS) were the major contributors to the biomass of the HDM, which indicated that the HDM has a high biological activity with attapulgite addition. Though the content of EPS and salts in cake layer were comparatively low, they had strong impacts on the DM structure and fouling since their deposition and adsorption on the membrane surface could result in severe pore blocking. The EPS is an important material which primarily acted as a film of pollutants [20]. It was found that the differences in the fouling degrees in the 
submerged DM bioreactors originated from different characteristics of the EPS exhibited at different SRT. The concentration of EPS is a good indicator of fouling propensity [20]. Similar trends have been reported by other researchers [19]. Seen from these studies on structure and composition of DM, it is known that addition of attapulgite to bioreactors is a reliable and effective approach in terms of improving biological removal and optimizing the structure of self-DM.

Table 3

Structure of the cake layer

\begin{tabular}{|l|c|c|c|c|}
\hline Bioeactor & $\begin{array}{c}\text { Content of DM } \\
\text { cake layer }\left[\mathrm{g} / \mathrm{m}^{2}\right]\end{array}$ & $\begin{array}{c}\text { EPS content } \\
{\left[\mathrm{g} / \mathrm{m}^{2}\right]}\end{array}$ & $\begin{array}{c}\text { VSS } \\
{\left[\mathrm{g} / \mathrm{m}^{2}\right]}\end{array}$ & $\begin{array}{c}\text { Mineral content } \\
{\left[\mathrm{g} / \mathrm{m}^{2}\right]}\end{array}$ \\
\hline DM & 38.12 & 8.83 & 25.96 & 5.34 \\
\hline HDM & 44.73 & 4.98 & 30.31 & 5.59 \\
\hline
\end{tabular}

\subsection{PARTICLE SIZE DISTRIBUTION}

Particle size distribution is an important index for assessing the efficiency of membrane bioreactors since it affects the characteristics of the cake formed and thereby influences the filtration process [21]. The particle size distribution may be explained by the growth rate of cells [19]. Larger microbial flocs (particles) have less contribution to the membrane fouling due to its high back-transport velocity by shear-induced diffusion.

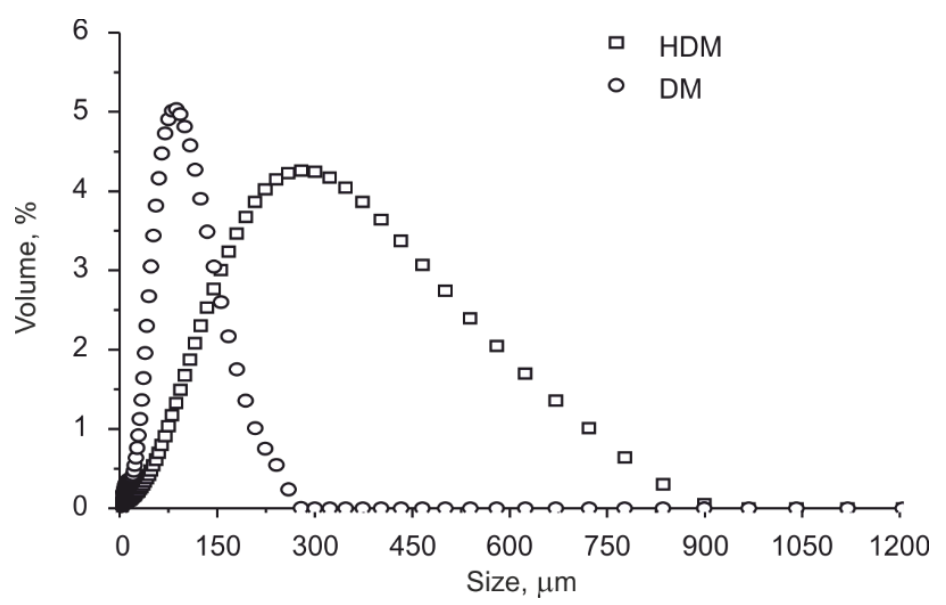

Fig. 4. The particle size distributions for DM and HDM

The particle size distributions for the DM in the two bioreactors are shown in Fig. 4. The average particle diameter increased from $130 \mu \mathrm{m}$ to $300 \mu \mathrm{m}$ after the addition of 
attapulgite, suggesting that smaller biological colloids and part of free bacteria coagulated, and larger aggregates formed with the addition of attapulgite. A similar phenomenon was also observed in membrane bioreactors with addition of other coagulants [22]. These results indicate that small particles in the DM have a strong tendency to deposit on the attapulgite surface during the operation of HDM bioreactors. Many researchers reported that larger sludge particles could be helpful to mitigate membrane fouling caused by sludge suspended particles [23]. A larger particle size distribution in the HDM bioreactors was a beneficial factor that could improve the filtration performance of HDM bioreactors relative to DM ones.

\subsection{SEM AND EDX ANALYSES}

SEM observations on the DM in the DM bioreactor were performed after filtration. The DM structure had non-uniform pore size and surface roughness. On the other hand, the HDM structure which was attached to the membrane material gave a bigger porosity with addition of attapulgite (Fig. 5). A previous study showed that dense layer of porous dynamic film was formed in the non-woven surface [19]. In order to identify the elements on the surface of the DM, EDX measurements were performed (Fig. 6). There are four extra elements $(\mathrm{O}, \mathrm{Mg}, \mathrm{Si}$ and $\mathrm{Fe})$ found on DM. The HDM contained much higher quantities of $\mathrm{Mg}, \mathrm{Si}$ and $\mathrm{Al}$ on the surface than DM did (Fig. 7).
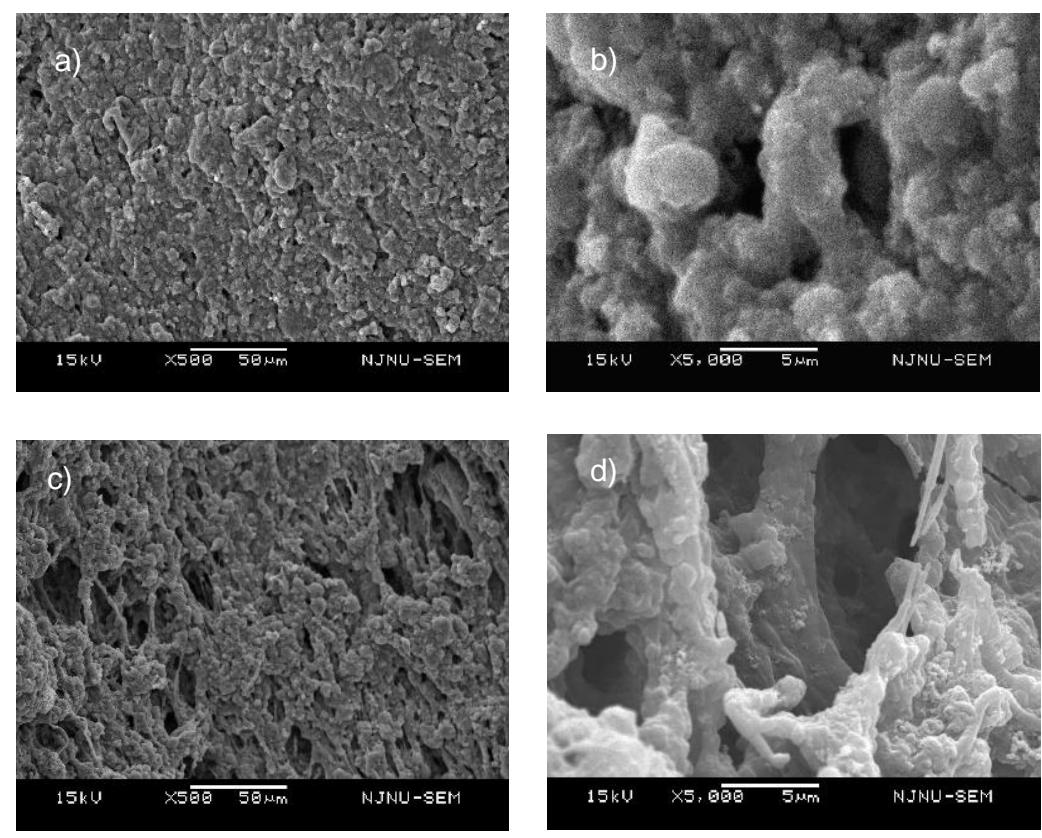

Fig. 5. Photographs of DM and HDM: a) DM, b) partially enlarged DM, c) HDM, (d) partially enlarged HDM 
These multivalent cations can form chemical precipitation with anions such as $\mathrm{SO}_{4}^{2-}, \mathrm{CO}_{3}^{2-}$, and $\mathrm{PO}_{4}^{3-}$ on the membrane surface [24] and/or function as a bridge to realize the biological precipitation on the membrane surface [25]. Wang et al. [23] reported that $\mathrm{Mg}, \mathrm{Fe}, \mathrm{Si}$ and $\mathrm{Ca}$ had significant effects on the formation of gel layers even when the quantity of these elements was low.

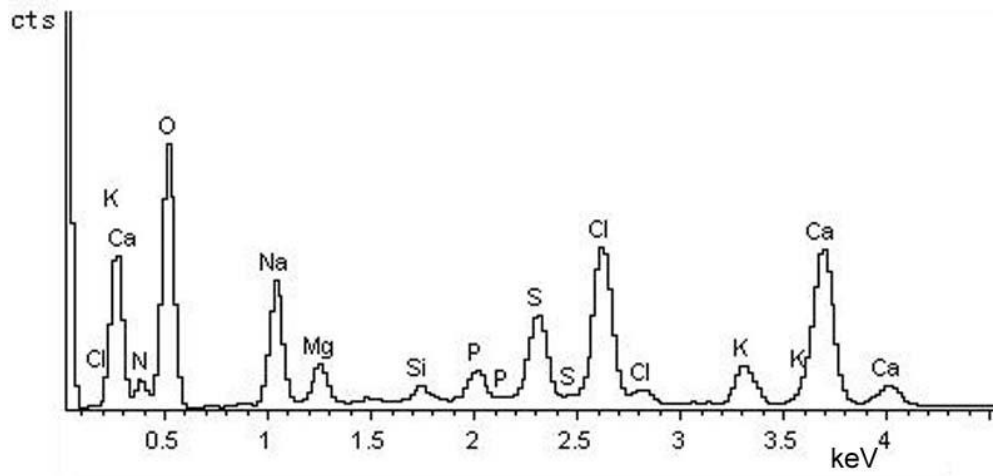

Fig. 6. EDX analysis of DM

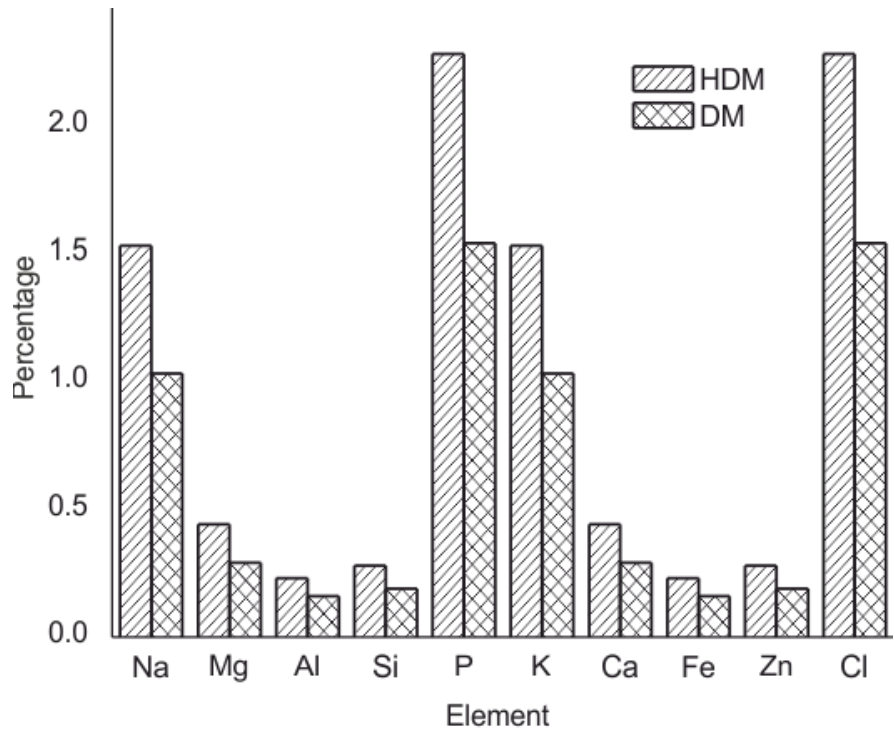

Fig. 7. Elements concentrations in the DM and HDM

\subsection{ANALYSES OF DGGE AND SHANNON DIVERSITY INDICES}

We used specific PCR amplification of 16S rDNA genes followed by DGGE to reveal the change of species population in activated sludge of DM in DM and HDM 
bioreactors. Figure 8 shows a DGGE gel image of PCR of the samples taken from the $\mathrm{DM}$ bioreactor systems with or without addition of attapulgite.

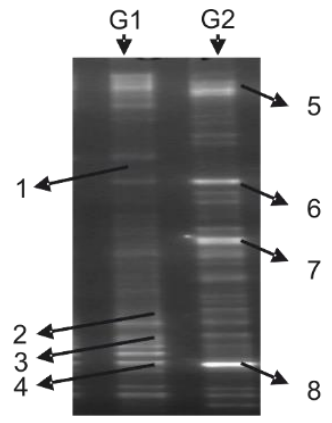

Fig. 8. DGGE profiles of bacteria in the sludge samples:

G1- analysis of bands $1-4$, DM bioreactor,

G2 - analysis of bands 5-8, HDM bioreactor

Populations and distribution of biological species in HDM bioreactors had a higher diversity than that those in DM bioreactors without attapulgite. The DGGE banding patterns did provide a means for measuring the apparent diversity of the community. Data analysis indicated that the chemical precipitation was attributed to $\mathrm{Al}, \mathrm{Si}$ and $\mathrm{Mg}$, as important constituents of attapulgite, which could be served as carriers of microorganisms. This mechanism contributed to improvement of biological removal in the attapulgite added DM bioreactor system including microbial degradation, membrane interception and attapulgite adsorption. In addition, the DGGE profile presented that the bacterial diversity of HDM was different from that of DM in the bioreactors, which was supported by the traditional Shannon diversity.

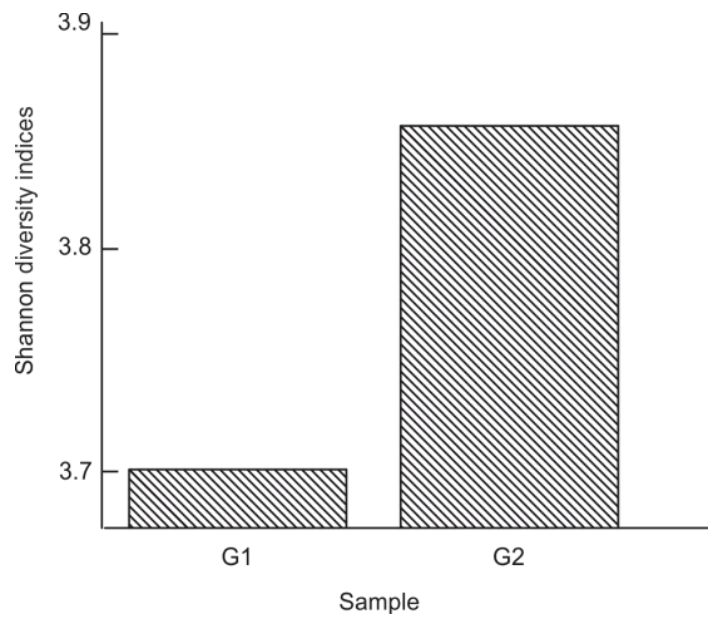

Fig. 9. Shannon diversity index: (G1) DM, (G2) HDM 
In the Shannon diversity index, each band corresponds to a unique species, and the density of each band is equivalent to the species abundance. The Shannon diversity index is influenced by both the species number and species abundance, and may be influenced by unknown factors related to the DNA extraction and the efficiency of the 16S gene amplification for particular populations. The Shannon diversity index of HDM bioreactor system was higher than that of DM one (Fig. 9), and the species activated sludge. The higher wastewater treatment performance could be attributed to higher Shannon diversity index in the AT-amended DM bioreactor system.

\section{CONCLUSIONS}

A HDM bioreactor has been developed via adding attapulgite into a conventional submerged DM bioreactor. Based on the results and analysis, we conclude as follows.

- Addition of attapulgite is a reliable and effective approach in terms of improvement both biological removal and structure of self-DM. The particle size distribution (PSD) of self-DM indicated an increase in microbial floc size with attapulgite adjunction. DM is mainly composed of particles of $130-300 \mu \mathrm{m}$.

- The content of cake layer of HDM and mineral elements in the HDM bioreactor system was $44.73 \mathrm{~g} / \mathrm{m}^{2}$ and $6.09 \mathrm{~g} / \mathrm{m}^{2}$, respectively. The concentration of EPS decreased after application of attapulgite in the HDM bioreactor system, whereas the volatile content of suspended particulate matter increased evidently.

- Self-DM has a porous structure with high porosity. The content of main elements such as $\mathrm{O}, \mathrm{Ka}, \mathrm{Ca}, \mathrm{P}, \mathrm{S}, \mathrm{Cl}, \mathrm{Mg}$ and $\mathrm{Si}$ displayed an increase trend in DM with addition of attapulgite. There is a correlation between the quantity of bacterial populations and improvement of biological removal.

\section{ACKNOWLEDGEMENTS}

This research was funded by the Priority Academic Program Development of Jiangsu Higher Education Institutions (PAPD) and the Doctoral Fund of the Ministry of Education of China (20110092120016) and the Innovation Funds of Anhui Normal University.

\section{REFERENCES}

[1] Williams M.D., PirbaZARi M., Membrane bioreactor process for removing biodegradable organic matter from water, Water Res., 2007, 41, 3880.

[2] GANDER M., JEFFERSON B., JUdD S., Aerobic MBRs for domestic wastewater treatment: a review with cost considerations, Sep. Purif. Technol., 2000, 18, 119.

[3] JANG N., Ren X., Cho J., KIM I.S., Steady-state modeling of bio-fouling potentials with respect to the biological kinetics in the submerged membrane bioreactor (SMBR), J. Membr. Sci., 2006, 284 (1-2), 352.

[4] NG H.Y., TAN T.W., ONG S.L., Membrane fouling of submerged membrane bioreactors: impact of mean cell residence time and the contributing factors, Environ. Sci. Technol., 2006, 40 (8), 2706. 
[5] KISO Y., JUnG Y.J., ICHINARI T., PARK M., KITAO T., Wastewater treatment performance of a filtration bio-reactor equipped with a mesh as a filter material, Water Res., 2004, 34 (17), 4143.

[6] Fuchs W., Resch C., Kernstock M., Mayer M., Schoeberl P., Braun R., Influence of operational conditions on the performance of a mesh filter activated sludge process, Water Res., 2005, 39 (5), 803.

[7] FAN B., HUANG X., Characteristics of a self-forming dynamic membrane coupled with a bioreactor for municipal wastewater treatment, Environ. Sci. Technol., 2002, 36 (23), 5245.

[8] Meng Z.G., YANG F.L., Zhang X.W., MBR focus: do nonwovens offer a cheaper option, Filtr. Sep., 2005, $42(5), 28$.

[9] SEO G.T., Moon B.H., LeE T.S., Lim T.J., Kim I.S., Nonwoven fabric filter separation activated sludge reactor for domestic wastewater reclamation. Water Sci. Technol., 2002, 47 (1), 133.

[10] Ronan T., Romuld T., Annabelle C., Dominique W., Annie T., Ozonation effect on natural organic matter adsorption and biodegradation. Application to a membrane bioreactor containing activated carbon for drinking water production, Water Res., 2010, 44, 781.

[11] Nicolas L., MathieU S., CoRINNE C., Study of a hybrid process. Adsorption on activated carbon/membrane bioreactor for the treatment of an industrial wastewater, Chem. Eng. Process., 2008, 47, 303.

[12] Chu H., CAO D., Jin W., Dong B., Characteristics of bio-diatomite dynamic membrane process for municipal wastewater treatment, J. Membr. Sci., 2008, 325 (1), 271.

[13] Al-Malack M.H., Anderson G.K., Cleaning techniques of dynamic membranes, Sep. Purif. Technol., 1997, 12, 25.

[14] CHEN H., WANG A.Q., Kinetic and isothermal studies of lead ion adsorption onto palygorskite clay, J. Colloid Interface Sci., 2007, 307, 309.

[15] Yan S.H., Clay M., Clay Miner, The Beijing Press Beijing China, 1981.

[16] DuAN W.S., Fu D.F., Influence of attapulgite on biological removal characteristics of hybrid dynamic membrane reactor, Fresen. Environ. Bull., 2011, 2943.

[17] Chinese NEPA. Water and Wastewater Monitoring Methods, 4th Ed., Chinese Environmental Science Publishing House, Beijing 2002.

[18] Ni B.J., FANG F., Characterization of extracellular polymeric substances produced by mixed microorganisms in activated sludge with gel-permeating chromatography, excitation-emission matrix fluorescence spectroscopy measurement and kinetic modeling, Water Res., 2009, 43, 1350.

[19] Fu D.F., DuAN W.S., HAN L.C., Study on dynamic membrane structure and component in sequencing batch reactor, CIESC J., 2009, 6 (60), 1568 (in Chinese).

[20] CHANG I.S., LEE C.H., Membrane filtration characteristics in membrane-coupled activated sludge system. The effect of physiological states of activated sludge on membrane fouling, Desalination, 1998, 120, 221.

[21] Meng F.G., Zhang H.M., YAng F.L., LiU L.F., Characterization of cake layer in submerged membrane bioreactor, Environ. Sci. Technol., 2007, 41 (11), 4065.

[22] WU J.L., HUANG X., Effect of dosing polymeric ferric sulfate on fouling characteristics, mixed liquor properties and performance in a long-term running membrane bioreactor, Sep. Sci. Technol., 2008, 63, 45.

[23] WANG Z.W., WU Z.C., YIN X., Tian L.M., Membrane fouling in a submerged membrane bioreactor (MBR) under sub-critical flux operation: membrane foulant and gel layer characterization, J. Membr. Sci., 2008, 325, 238.

[24] Meng F., Chae S.R., Drews A., Kraume M., Shin H.S., Recent advances in membrane bioreactors (MBRs): membrane fouling and membrane material, Water Res., 2009, 43, 1489.

[25] SEIDEl A., ElimeleCh M., Coupling between chemical and physical interactions in natural organic matter (NOM) fouling of nanofiltration membranes, Implication for fouling control, J. Membr. Sci., 2002, 203, 245. 